\title{
A Comparative Study of Traditional Activity-based Costing and Time-driven Activity-based Costing at a University Hospital in South Korea
}

\author{
Keun-Hyo Yook \\ School of Business Administration, Busan University of Foreign Studies \\ Geumjeong-gu, Pusan, 609-815, Korea \\ yook@bufs.ac.kr \\ Sung-Wook Yi \\ College of Business and Economics, Hanyang University \\ 55 Hanyangdaehak-ro Sangnok-gu, Ansan, Gyeonggi-do, 426-791 Korea \\ swyi@hanyang.ac.kr \\ Il-woon Kim* \\ George W. Daverio School of Accountancy, The University of Akron \\ 259 South Broadway Street, Akron, OH 44308, U.S.A. \\ ikim@uakron.edu
}

\begin{abstract}
Due to serious problems associated with activity-based costing (ABC), time-driven activity-based costing (TDABC) was recently suggested as a better alternative. TDABC is designed to enhance the objectivity of data collection and decrease time and cost as well. However, the accuracy of the allocated costs using TDABC has not been widely tested yet, particularly in the healthcare industry. The objective of this study is to review the differences between $\mathrm{ABC}$ and TDABC and apply both techniques to a university hospital in South Korea to evaluate the results of cost allocation of outpatient nursing activities in Pediatrics Department. It is shown that the allocated costs are not very different between the two techniques, which implies that TDABC can be effectively used to compute the cost of each patient accurately. The result of this study also demonstrates that, using TDABC, the visibility of unused resources will be improved at all levels of management in the hospital, and non-value added activities can be managed effectively using the information regarding the activity ratios of traditional $\mathrm{ABC}$ and TDABC. In addition, it is shown that the accurate cost report to each doctor can provide a motivation for doctors to improve their profitability.
\end{abstract}

Keywords: Activity-based costing; Time-driven activity-based costing, health care industry

DOI: $10.7176 /$ RJFA/10-10-01

Publication date:May $31^{\text {st }} 2019$

\section{Introduction}

The financial performance of a hospital is very sensitive to changes in the external environment, such as government regulations on healthcare, medical insurance policies, medical technology advancements, the political environment, and the economy in general. In addition, global competition in the healthcare industry has been increasing rapidly during the last decade, and rising healthcare costs has been a major economic, social and political issue in the United States and many other countries around the world.(Amadeo, 2019; Cook et al., 2014; Pearl, 2017; Seuring et al., 2015) Most of these external factors are difficult or impossible for the individual hospitals to control; however, depending on to the response to the environmental changes and how they are managed internally, these factors can be an opportunity or threat to individual hospitals. Therefore, the internal business environment that consists of the corporate culture and management system should be adaptable to changes in the external environment. As part of the internal environment, cost management has been recognized as one key financial factor for a hospital to become profitable and competitive in the healthcare industry. That is why many hospitals have been focusing on activity-based costing (ABC) since the early 2000 to improve their cost management systems. In contrast to the traditional system allocating overhead based on volume measures (e.g., direct labor hours and production volume), ABC allocates overhead costs based on the activities that cause the overhead costs to be incurred. In a typical ABC system, overhead costs are allocated in two stages: from resources to activities and from activities to cost objects. In the process, many non-volume measures are used as cost drivers, such as the number of inspections, the degree of complexities, and the number of purchases, to improve the accuracy of the product costs.

$\mathrm{ABC}$ is particularly effective for those companies whose products are diversified and whose overhead costs are significant relative to their direct costs. In the healthcare industry, hospitals provide extremely diversified 
services to their patients, and their overhead costs have recently been rapidly increasing due to the increasing use of computers and equipment. Hence, more hospitals are interested in $\mathrm{ABC}$, and many hospitals are currently using a type of $\mathrm{ABC}$ in the overhead cost allocation process. However, there are issues in applying $\mathrm{ABC}$ in a hospital setting to achieve the originally intended objective. First, although the concept of $\mathrm{ABC}$ is simple, the actual procedure to introduce $\mathrm{ABC}$ is complicated and often challenging to follow. It can be very costly and timeconsuming to train the employees of an organization introducing $\mathrm{ABC}$, and this is particularly true for hospital employees who do not have a manufacturing background. It should be noted that $\mathrm{ABC}$ was initially created to address manufacturing overhead costs, and most articles and cases in the literature address manufacturing companies. Second, the data collection and system setup required in the introduction stage can be an enormous task. Hospitals usually would not maintain detailed records of their activities, individual costs, and cost drivers as often as manufacturing companies. Third, once an $\mathrm{ABC}$ system is established, the system should be periodically updated because activities, costs, and activity drivers are constantly changing due to the numerous changes occurring in the organization. If the system is not updated on time, the cost information generated will not be as accurate as expected. In reality, maintaining the system can also be costly and time-consuming for hospitals. Recognizing that these three general issues had been primary obstacles for many companies considering the use of ABC, Kaplan and Anderson (2004) proposed Time-Driven Activity-Based Costing (TDABC), which is not only simple for data collection and system setup but also easy to maintain the system.

The objectives of this study are three fold. First, we will develop a TDABC system based on the outpatient nursing activities in the Pediatrics Department of a university hospital in South Korea and compare the outpatient nursing costs of TDABC with those of their existing ABC system, which has been in place for a few years. The costs of the operational (i.e., patients' care) units and supporting units will be computed separately to examine the causes of any differences between the two systems. It is expected that the results will help examine the effectiveness of TDABC at the hospital. Second, we will examine how the cost of the unused capacity should be identified and managed to maximize the efficiency of each resource (i.e., doctor's time). It is expected that the results will provide useful information to develop a strategy to improve the efficiency in using internal resources and managing nursing costs. For example, the computation of the resource capacity will provide valuable information for resource planning, and non-value added activities can be managed effectively using the information regarding the activity ratios of traditional $\mathrm{ABC}$ and TDABC. In addition, accurate cost allocation to each doctor will provide a motivation for doctors to improve their profitability. Third, we will identify additional information available in comparing $\mathrm{TDABC}$ to traditional $\mathrm{ABC}$, and we will provide suggestions for improving the effectiveness of TDABC.

Following the introduction, Part 2 describes theoretical and practical backgrounds of traditional $\mathrm{ABC}$ and TBABC and explains the major differences of the two costing techniques. A literature review is provided in Part 3. Research methodology will be discussed in Part 4, including the study subjects, surveys on outpatient nursing activities, data collection process, and costing system of the study hospital. Part 5 will present a case study regarding the use of $\mathrm{ABC}$ and $\mathrm{TDABC}$ at a hospital in allocating the costs of outpatient nurses, and the differences between traditional $\mathrm{ABC}$ and TDABC will be examined in detail. A summary and implications of the study are presented in Part 6.

\section{Theoretical background}

\subsection{Traditional Activity-based Costing}

ABC was originally developed in the early 1980s in an attempt to compute product costs accurately when overhead costs were increasing rapidly because of the diversification of products and advancement of manufacturing technologies. Under the traditional costing system prior to $\mathrm{ABC}$, it was believed that costs were incurred because of cost objects (e.g., products), and the costs were directly assigned to the products with the allocation of overhead based on volume-related measures. (Wikipedia, March 2017) ABC, however, collects cost data for the activities that consume the resources of an organization and assigns costs to various cost objects such as products, services and customers. Costs are not directly traced to each cost object; instead, they are assigned to the cost objects based on the cause-and-effect between activities and cost objects.

Although $\mathrm{ABC}$ is much more complicated than the traditional costing system, there are many advantages in using $\mathrm{ABC}$ for business. First, we can select more appropriate overhead cost allocation bases mainly because costs are accumulated, not by each department and function, but by the activities that are well diversified and detailed. Accordingly, the product costs under $\mathrm{ABC}$ will be more accurate than those under the traditional costing system. Second, ABC can recognize various cost drivers and show their cause-and-effect relations with the costs; thus, it is possible to manage costs effectively. For example, based on the knowledge of cost drivers, we can identify the activities consuming most resources and attempt to reduce their cost drivers to ensure that costs can be reduced proportionately. Third, with more accurate ABC costs, pricing and profitability decisions can be made more realistically. $\mathrm{ABC}$ is known to be particularly effective in making product mix decisions. Last, the traditional costing system solely provides financial information regarding the cost objects, whereas ABC provides detailed 
financial as well as nonfinancial information regarding the activities. Hence, ABC information can be used to measure the efficiency of operations of the entire organization. A performance evaluation will be more accurately performed using $\mathrm{ABC}$ information, and communication with production and other operating managers can be significantly improved.

\subsection{Time-driven Activity-based Costing}

It is clear that $\mathrm{ABC}$ can be used to prevent product costs from being distorted using the simple traditional allocation approach and to compute product costs more accurately to ensure that managers can make better business decisions. Efficiency can also be improved through activity-based management (ABM) by providing information necessary for internal operations that can add value to the organization. (Cooper and Kaplan, 1998) However, a major disadvantage of $\mathrm{ABC}$ systems lies in the high time and cost associated with the estimation of a cost model and the management of complex cost-accounting techniques (Kaplan and Anderson, 2004). Everaert et al. (2008) claim that many managers who have attempted to implement $\mathrm{ABC}$ in their organizations, including healthcare managers, have abandoned the attempt because of rising costs and employee irritation.

Certain studies have identified these problems and provided suggestions for improvement. Lievens et al. (2003) introduced an extra allocation step between activity groups and activities to avoid a complex allocation principle with a large diversity of cost drivers. Cao et al. (2006) also tested a modified version of ABC that could reduce the number of cost drivers in hospitals. Further studies were performed using a revised version of the traditional ABC. For example, Storfjell et al. (2008 and 2009) conducted a study that determined nonvalue-added (NVA) time and costs of an acute care nursing unit staff, identified drivers of high-cost NVA time, and compared activities and costs by the type of nursing unit. This revised version, however, was based on the traditional model with certain improvements without innovative ideas. To overcome the difficulties with ABC, Kaplan and Anderson (2004 and 2007) developed TDABC, which is truly innovative and effective.

TDABC can compute the activity costs based solely on two time measures and, at the same time, evaluate the efficiency of resources being used within the organization. These two time measures regarding the resource consumption of activities are generally available in the database or can be estimated by the manager in charge of each department. The first measure is the cost per time unit of the resource capacity. The cost of supplying the theoretical resource capacity is computed; then the cost of practical resource capacity will be estimated based on the theoretical capacity by the manager to ensure that the actual allocation can be performed in a realistic setting. Practical capacity is the total time that one would actually take to perform a specific task during work hours in a realistic setting. Kaplan and Anderson (2004) state that the employees spend their time during work hours for breaks, training, and communication, which are not directly related to their specific jobs assigned; therefore, the practical capacity can be estimated as $80 \%$ to $90 \%$ of the theoretical capacity. Machines can also have a downtime of $10 \%$ to $20 \%$ caused by maintenance, repair, and scheduling. Using the theoretical capacity without considering personal time and downtime, the applications of the costs computed would be limited, and it would be difficult to make correct decisions in utilizing resources effectively and evaluating the efficiency of operations. The practical resource capacity is flexible and can be adjusted to meet corporate policies or rules, and it can be increased when the company plans to pursue enhancement of operational efficiency beyond its current level. Hence, in estimating the practical capacity, it is usually sufficient to review and determine the organization's vision and objectives. Large-scale surveys, interviews and/or observations, which can be costly and time consuming, are generally not necessary.

The second measure necessary to implement TDABC is the unit times of activities. Unit times can be estimated based simply on an interview by managers or occasionally on the observations of experienced workers and/or their opinions. A major advantage of using the unit times is that extensive surveys, observations, and/or interviews would not be necessary to collect the activity information. Kaplan and Anderson (2004) state that there can be errors in estimating these two measures by managers; however, these errors can be analyzed and adjusted in the process of investigating the final costs generated by TDABC. Kaplan and Norton (2008) argue that, because the productivity data for process improvements and the likely sales numbers can be available under TDABC, companies can now estimate what resources they will need a in a year to execute their strategic goals.

Because TDABC can compute the product cost using a time equation that is based on the process time required, it does not require the collection and maintenance of a large quantity of activity data. Although the theoretical capacity is assumed in traditional costing method of ABC, TDABC uses the practical capacity to reflect more realistic cost information into the product cost. Another major advantage of TDABC is that it computes the cost of unused capacity and thereby helps the organization decide correctly regarding the use of scarce resources. Based on the cost efficiency of each input, unused resources can be reallocated to maximize the overall efficiency. In addition, TDABC is different from the traditional costing approach, which focuses solely on the accuracy of costs, in that more realistic alternatives and strategies can be developed through the internal product costing process. (Kaplan and Anderson, 2007) 


\section{Literature Review}

Although ABC was first introduced in the early 1980s, for a variety of reasons, ABC was not applied to hospitals in the U.S. until the mid-1990s. The first reason was the rapid increase of healthcare costs in the 1990s. Demeere et al., (2009) note that healthcare managers are continuously urged to provide better patient services at a lower cost and that, to cope with increasing cost pressures, healthcare management needs to improve its understanding of the relevant cost drivers. The second reason was the difference in cost accounting systems of hospitals from those of commercial or manufacturing firms. In contrast to these firms, the business outcome is difficult to define in hospitals because various types of services are provided as a package and the health care delivery system is complex (Kaplan and Porter, 2011). The portion of joint and common costs is also much higher; therefore, it is important to allocate overhead systematically in hospitals. In addition, an efficient inventory control system on the consumption of medical materials is necessary (Yereli, 2009). These previous studies have shown that the accuracy of cost is improved significantly using $\mathrm{ABC}$ in the healthcare industry.

In certain studies, benchmarking based on $\mathrm{ABC}$ information for budgeting and service and facility competitiveness is suggested. (Yereli, 2009; Lin et al., 2007; Lievens et al., 2003) The introduction of ABC to the healthcare industry has also changed the manner in which hospitals manage their nursing costs. Carr (1993) provides an example of the process of developing an ABC system for nursing service at a rehabilitation center. In that study, three skill levels of nursing services are identified, and this process allows them to manage staffing more efficiently. Ramsey (1994) develops two hypothetical examples of applying ABC to nursing stations. In their two studies using the ABC approach, Storfjell et al. (2008 and 2009) analyze the percent of time that nurses spent performing key patient care and supportive nursing activities. The researchers have found that there is a strong relation between the quantity of non-value-added (NVA) time (system inefficiencies) and patient safety and quality. Therefore, reducing NVA time should have the dual effect of reduced costs and improved quality.

A small number of studies applied TDABC to hospitals to present its usefulness and implications for strategic decision making. Demeere et al. (2009) attempt to explain the development, the relevance and the managerial impact of TDABC in an outpatient clinic environment. The researchers show that the TDABC system provides accurate and relevant information to healthcare managers and physicians and assists them in improving operations, conducting a profitability analysis for each department, and making decisions on future investments. Bank and Mcllrath (2009) conduct a study using data from a high volume pediatric emergency department (ED) in a freestanding children's hospital. It is shown that the TDABC analysis can be used by ED directors to help determine the allocation of ED clinical resources. It is also demonstrated that the TDABC analysis of service can be used as a tool to help develop professional and facility reimbursement strategies with commercial payers. To observe how TDABC works in the health care context, Kaplan and Porter (2011) explore a simplified example and show three major benefits of TDABC: opportunities to improve value (e.g., eliminating unnecessary process variations that do not add value, improving resource capacity utilization, and speeding up cycle time), capturing the payoffs, and reinventing reimbursement. The researchers show that, with appropriate estimates of the typical path that an individual patient takes for a medical condition, care providers can use TDABC system to assign costs accurately and relatively easily to each process step along the path. It should be noted that none of these studies reviewed in this section compare the results of TDABC with those of traditional ABC.

\section{Research Design}

\subsection{Study Subject}

This study was conducted at a University Hospital located in South Korea. The hospital opened in 1975 and currently has 1,200 beds with 1,800 staff members (770 nurses, 110 nurse assistants, and 920 support personnel). In the hospital, we selected the Pediatrics Department because of its easy access to data and its willingness to participate in our study comparing traditional ABC and TDABC in their own unit. ${ }^{1}$

There were nine doctors, three nurses and two assistants in the Pediatrics Department. Our study was limited to outpatient nursing activities in the department. For the purpose of this study, the outpatient nursing activities were initially classified into two domains: patient care and support. Patient care was further classified into two categories of reservation/ushering and treatment/diagnosis, and support was classified into two categories of cooperation/adjustments and administration. Typical activities for each category are listed in Figure 1. Certain individual activities are commonly combined and/or slightly altered in developing an actual ABC system for different departments.

\footnotetext{
${ }^{1}$ The administrators of the hospital were very interested in this project mainly because traditional ABC had been initiated in 2008 and fully installed in 2009 as a means to improve the overall cost management of the hospital.
} 
$\|$ IIS

Figure 1. Outpatient Nursing Activities

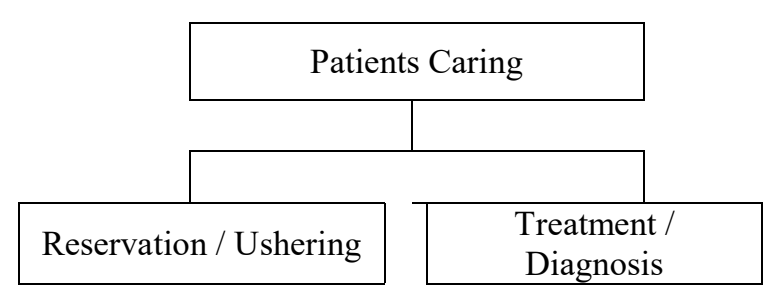

Reservation

Ushering

Consultation with patients

Consultation with guardians

Education
Treatment

Diagnostic support

Recording

Injection

Surgery - related

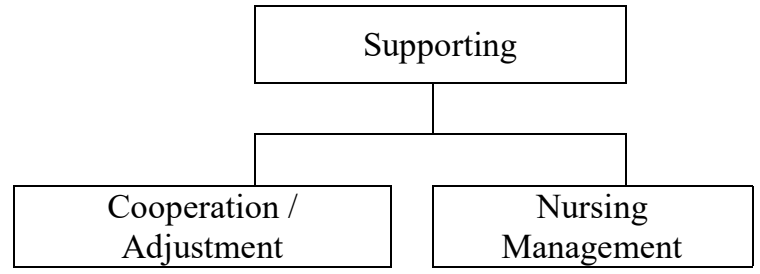

Schedule maintenance

Requisition supplies

Managing supplies

Cooperation

Meetings
Administration

Clerical

Education

Training

The rationale behind using the nursing activities is that, as noted by Storfjell et al. (2008), the nursing wages constitute a high proportion of a hospital's budget and understanding the costs of activities is critical to manage them. Another study by Storfjell et al. (2009) also shows that a considerable amount of nursing time is consumed by non-patient care and non-value added activities.

\subsection{Data Collection and Costing Model}

For data collection, we met the hospital's cost management team and nursing staff at Pediatrics Department several times and explained the objective of the study. We also trained the team and staff regarding the basic concept of $\mathrm{ABC}$ and data collection process. The team and staff agreed to fully cooperate because they were also very interested in the results of the study.

The information required for the study was collected from two different sources in the hospital. General information regarding the activities of the outpatient nurses was collected from their traditional ABC system that was currently in place. From the same source, the information regarding the percentages of nursing activities of the total activities was collected. The second source of information was the survey of the outpatient nurses involved in the study. The nurses were trained to input their actual time spent for each activity and the frequency of each activity on their daily activity sheet.

Figure 2 shows the information flow under the existing $\mathrm{ABC}$ for the hospital. ABC information is saved and transmitted through the Order Communication System (OCS). Profit information is recognized through the clinic support system, which is used to manage diagnosis statistics systematically, and information on wages is extracted through the personnel payroll system. Information on supplies/medicines, operating expenses and depreciation is extracted through the purchasing system, accounting system, and fixed asset management system, respectively. Information regarding the activities is extracted through the hospital web system and ERM, which represents the hospital's unit nursing activity codes. ABC cost data can be obtained from the cost computation and reporting system coming from each system described above. 
Figure 2. Traditional ABC System at the Hospital

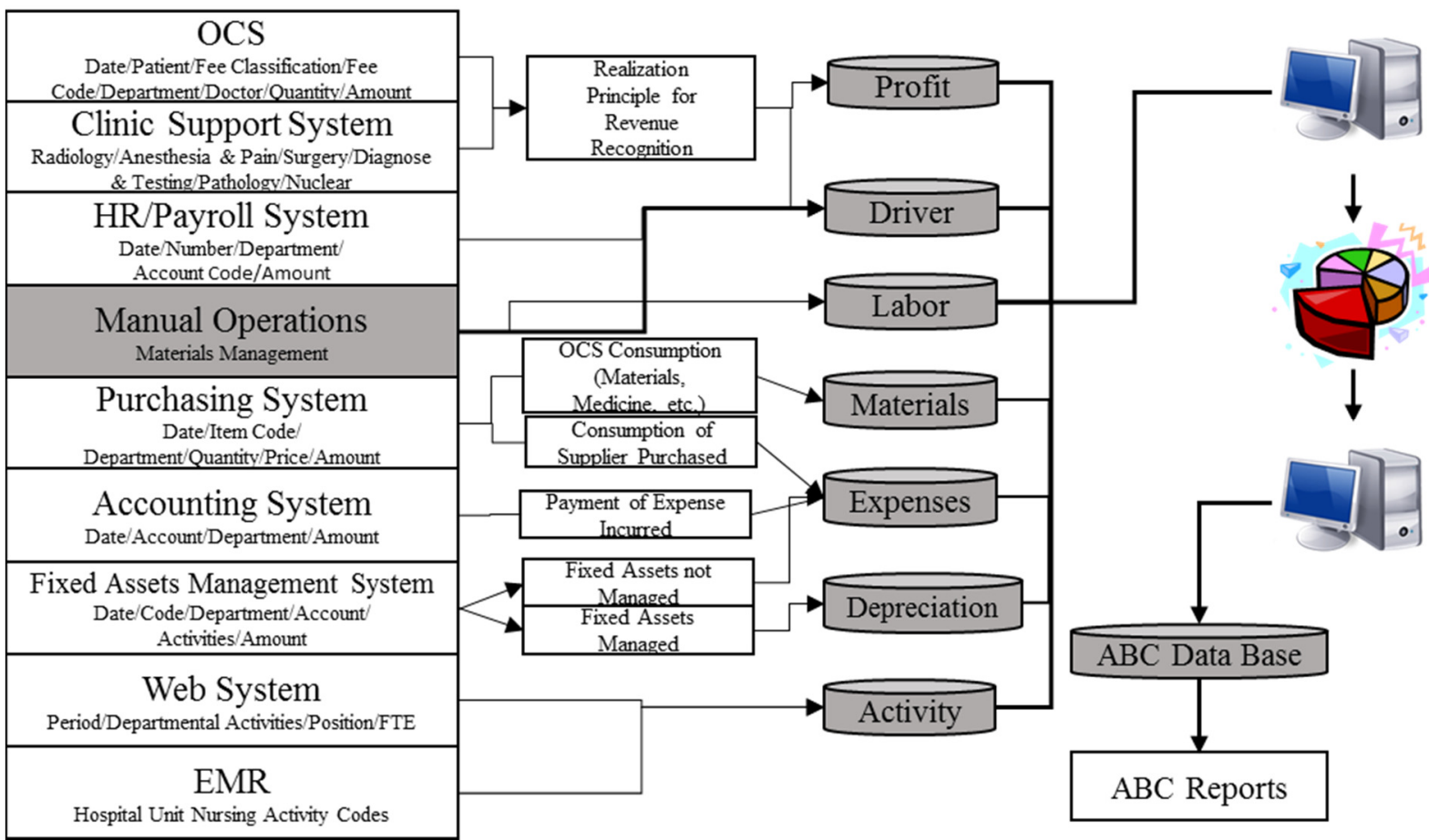

\section{Results Analysis}

Because of the confidential nature of financial data in the hospital, we used artificial numbers for the wages of outpatient nurses. We assumed that the monthly average wage paid at Pediatrics Department was $\$ 300,000$ in total. ${ }^{1}$

\subsection{Costs of Outpatient Nursing Activities under Traditional ABC}

Outpatient nursing activities under the traditional $\mathrm{ABC}$ are listed in Figure 3, in addition to the definition of each activity and the cost driver as the allocation base for each activity. ${ }^{2}$ Two allocation bases that are mainly being used are the number of outpatients and FTE (full time equivalent) in each department. FTE is the amount of oneday work of a full-time employee. For example, if one person performed half of the daily work load, FTE will be recorded as 0.5 .

\footnotetext{
${ }^{1}$ Although the actual costs were not used in this study because of the confidentiality of cost information at the hospital, $\$ 300,000$ (approximately $312,000,000$ won in Korean currency) would be an estimation sufficiently reasonable to demonstrate the differences in traditional $\mathrm{ABC}$ and TDABC.

${ }^{2}$ This is the general list of the activities and activity bases for the entire hospital to ensure that certain activities are applicable solely to specific departments. For example, child birth, delivery and sick leave are applied solely to the Ob/Gyn Department.
} 
Figure 3. Overhead Cost Allocation Bases under Traditional ABC

\begin{tabular}{|c|}
\hline$<$ Activity Name $>$ \\
\hline Education \& Training \\
\hline Recording \& Statistics \\
\hline $\begin{array}{c}\text { Consultation \& Education } \\
\text { (Patients) }\end{array}$ \\
\hline Discussion \& Meeting \\
\hline Reservation/Reception/Ushering \\
\hline Injection \& Surgery Support \\
\hline Managing Diagnose Schedule \\
\hline $\begin{array}{c}\text { Diagnose Environment \& } \\
\text { Sanitation }\end{array}$ \\
\hline Managing Patients' Charts \\
\hline Treatment/Diagnose Support \\
\hline Childbirth, Delivery/Sick Leave \\
\hline $\begin{array}{c}\text { Supplies Requisition \& } \\
\text { Management }\end{array}$ \\
\hline $\begin{array}{c}\text { Inputting Diagnosis \& } \\
\text { Preseriptions }\end{array}$ \\
\hline
\end{tabular}
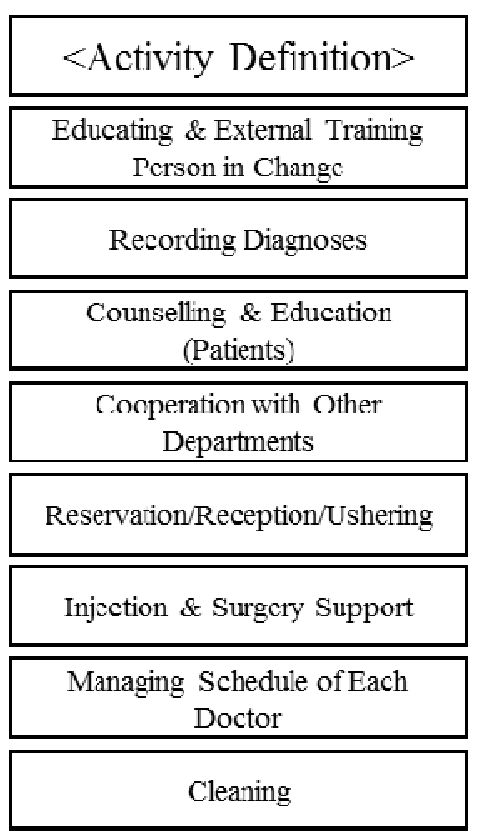

Managing Patients' Charts

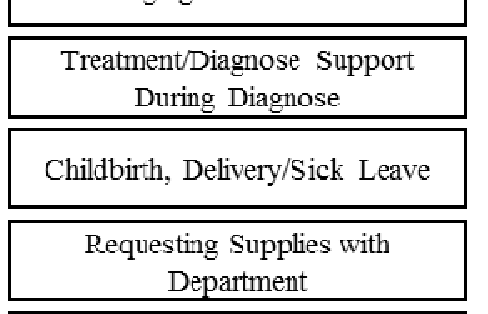

Inputting Diagnosis \& Prescriptions

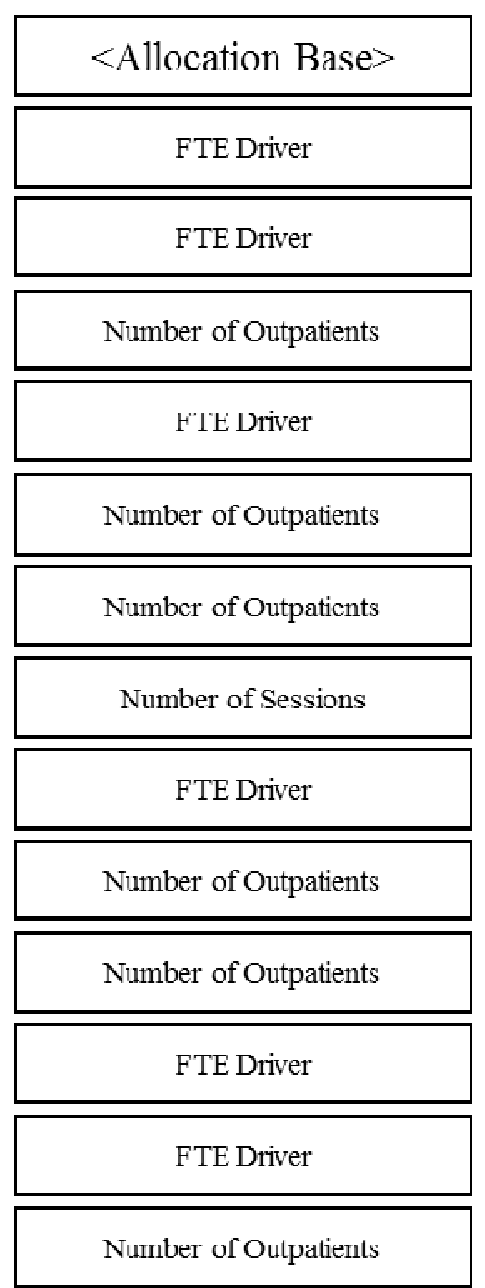

Table 1 shows the activity ratios under traditional ABC applied to the Pediatrics Department. Note that the patient care activities use as much as $86.9 \%$ of total nursing activities, while the support activities only use $13.1 \%$. Among the area of patient care activities, $78.5 \%$ is for medical treatment and support and $21.5 \%$ is for reservation and ushering. The last column of the table shows that the treatment/diagnosis support category has the highest ratio with $30.4 \%$ of the total activities, and the consultation and education category has the lowest with $6.3 \%$. Among the support activities as the second category, 9.1\% $(8.4 \%+0.7 \%)$ is from cooperation and adjustment activities, and 3.9\% $(1.6 \%+1.6 \%+0.7 \%)$ is from administration. Interestingly, Storfjell et al. (2008 and 2009) show that the ratio of support activities is higher than that of patient care nursing activities: $56 \%$ for support activities and $44 \%$ for patient care activities. This opposite result is caused by the difference in activity classification in the two studies. In our study, the reservation/ushering activities are included in patient care activities, whereas the same activities are included in support activities in the Storfjell et al. studies.

As the first stage of implementing ABC, the total estimated nursing costs of $\$ 300,000$ were initially allocated to each activity based on the activity ratio in the last column of Table 1 . In the second stage of the process, the cost of each activity was then allocated to each Pediatrics doctor based on the consumption ratios of the activities, which were available in the traditional $\mathrm{ABC}$ system. The results of the two-stage allocation are presented in Table 2. Because traditional $\mathrm{ABC}$ is using the number of outpatients as a major cost driver, Doctor A, who had the most outpatients, had the highest allocation of $\$ 66,296$ (21.1\%), and Doctor E had the next highest allocation of $\$ 45,269$ (15.1\%). The lowest allocation was for Doctor $\mathrm{H}$, which was $\$ 16,038$ (5.4\%). 
Table 1. Activity Ratios in the Pediatrics Department Using Traditional ABC

\begin{tabular}{|c|c|c|c|}
\hline Domain & Category & Activity & Activity ratio \\
\hline \multirow{6}{*}{$\begin{array}{l}\text { Patient caring } \\
(86.9 \%)\end{array}$} & \multirow{2}{*}{$\begin{array}{l}\text { Reservation } \quad \& \\
\text { ushering }\end{array}$} & Reservation, registration \& ushering & $12.4 \%$ \\
\hline & & $\begin{array}{l}\text { Consultation \& education (for patient and } \\
\text { guardian) }\end{array}$ & $6.3 \%$ \\
\hline & \multirow{4}{*}{$\begin{array}{l}\text { Medical treatment } \\
\text { \& support }\end{array}$} & Treatment \& diagnosis support & $30.4 \%$ \\
\hline & & Inputting diagnosis \& prescription & $19.7 \%$ \\
\hline & & Managing patients' charts & $10.0 \%$ \\
\hline & & Diagnosis environment $\&$ sanitation & $8.1 \%$ \\
\hline \multirow{5}{*}{$\begin{array}{l}\text { Supporting } \\
(13.1 \%)\end{array}$} & \multirow{2}{*}{$\begin{array}{l}\text { Cooperation } \quad \& \\
\text { adjustments }\end{array}$} & Managing diagnosis schedules & $8.4 \%$ \\
\hline & & Meetings \& discussions & $0.7 \%$ \\
\hline & \multirow{3}{*}{ Administration } & Requisitioning \& managing supplies & $1.6 \%$ \\
\hline & & Recording \& statistics & $1.6 \%$ \\
\hline & & Education \& training & $0.7 \%$ \\
\hline \multicolumn{2}{|c|}{ Total } & & $100.0 \%$ \\
\hline
\end{tabular}

Table 2. Allocated Costs for Each Doctor in the Pediatrics Department Using Traditional ABC

\begin{tabular}{|l|c|c|c|c|c|c|c|c|c|}
\hline \multicolumn{1}{|c|}{ Activity } & $\begin{array}{c}\text { Doctor } \\
\text { A }\end{array}$ & $\begin{array}{c}\text { Doctor } \\
\text { B }\end{array}$ & $\begin{array}{c}\text { Doctor } \\
\text { C }\end{array}$ & $\begin{array}{c}\text { Doctor } \\
\text { D }\end{array}$ & $\begin{array}{c}\text { Doctor } \\
\mathbf{E}\end{array}$ & $\begin{array}{c}\text { Doctor } \\
\mathbf{F}\end{array}$ & $\begin{array}{c}\text { Doctor } \\
\mathbf{G}\end{array}$ & $\begin{array}{c}\text { Doctor } \\
\text { H }\end{array}$ & Total \\
\hline $\begin{array}{l}\text { Reservation, } \\
\text { registration, \& } \\
\text { ushering }\end{array}$ & $\$ 8,490$ & $\$ 5,056$ & $\$ 4,137$ & $\$ 3,485$ & $\$ 5,655$ & $\$ 5,535$ & $\$ 2,889$ & $\$ 1,917$ & $\$ 37,164$ \\
\hline $\begin{array}{l}\text { Consultation \& } \\
\text { education }\end{array}$ & $\$ 4,296$ & $\$ 2,559$ & $\$ 2,093$ & $\$ 1,763$ & $\$ 2,861$ & $\$ 2,801$ & $\$ 1,462$ & $\$ 970$ & $\$ 18,806$ \\
\hline $\begin{array}{l}\text { Treatment \& } \\
\text { diagnosis support }\end{array}$ & $\$ 24,671$ & $\$ 14,694$ & $\$ 12,021$ & $\$ 10,127$ & $\$ 16,433$ & $\$ 16,086$ & $\$ 8,396$ & $\$ 5,572$ & $\$ 108,000$ \\
\hline $\begin{array}{l}\text { Inputting diagnosis } \\
\text { \& prescription }\end{array}$ & $\$ 13,502$ & $\$ 8,041$ & $\$ 6,579$ & $\$ 5,542$ & $\$ 8,993$ & $\$ 8,803$ & $\$ 4,595$ & $\$ 3,049$ & $\$ 59,104$ \\
\hline $\begin{array}{l}\text { Managing patients' } \\
\text { charts }\end{array}$ & $\$ 6,853$ & $\$ 4,082$ & $\$ 3,339$ & $\$ 2,813$ & $\$ 4,565$ & $\$ 4,468$ & $\$ 2,332$ & $\$ 1,548$ & $\$ 30,000$ \\
\hline $\begin{array}{l}\text { Diagnostic } \\
\text { environment \& } \\
\text { sanitation }\end{array}$ & $\$ 3,860$ & $\$ 3,043$ & $\$ 2,796$ & $\$ 2,920$ & $\$ 3,377$ & $\$ 3,798$ & $\$ 2,561$ & $\$ 1,645$ & $\$ 24,000$ \\
\hline $\begin{array}{l}\text { Managing } \\
\text { diagnosis schedules }\end{array}$ & $\$ 1,383$ & $\$ 1,090$ & $\$ 1,002$ & $\$ 1,046$ & $\$ 1,210$ & $\$ 1,361$ & $\$ 917$ & $\$ 589$ & $\$ 8,598$ \\
\hline $\begin{array}{l}\text { Meetings \& } \\
\text { discussions }\end{array}$ & $\$ 506$ & $\$ 304$ & $\$ 250$ & $\$ 212$ & $\$ 340$ & $\$ 334$ & $\$ 176$ & $\$ 117$ & $\$ 2,239$ \\
\hline $\begin{array}{l}\text { Requisitioning \& } \\
\text { managing supplies }\end{array}$ & $\$ 1,114$ & $\$ 669$ & $\$ 549$ & $\$ 466$ & $\$ 748$ & $\$ 735$ & $\$ 388$ & $\$ 257$ & $\$ 4,925$ \\
\hline $\begin{array}{l}\text { Recording \& } \\
\text { statistics }\end{array}$ & $\$ 1,114$ & $\$ 669$ & $\$ 549$ & $\$ 466$ & $\$ 748$ & $\$ 735$ & $\$ 388$ & $\$ 257$ & $\$ 4,925$ \\
\hline $\begin{array}{l}\text { Education \& } \\
\text { training }\end{array}$ & $\$ 506$ & $\$ 304$ & $\$ 249$ & $\$ 212$ & $\$ 340$ & $\$ 334$ & $\$ 176$ & $\$ 117$ & $\$ 2,238$ \\
\hline \multicolumn{1}{|c|}{ Total } & $\$ 66,296$ & $\$ 40,510$ & $\$ 33,563$ & $\$ 29,051$ & $\$ 45,269$ & $\$ 44,991$ & $\$ 24,281$ & $\$ 16,038$ & $\$ 300,000$ \\
\hline
\end{tabular}

5.2 Costs of Outpatient Nursing Activities under TDABC

The cost allocation model under TDABC is presented in Figure 4. In each department, standard activities and standard times are defined, and the quantity of outpatient nursing activities is measured by the multiplication of standard time and frequency of the type of each activity (resource driver). Activity ratios are then estimated based on the quantity of activities, and the costs of nursing activities are determined using the activity ratios. These costs are finally allocated to each doctor based on the weight of each activity by the doctor. 
Figure 4. Cost Allocation System under TDABC

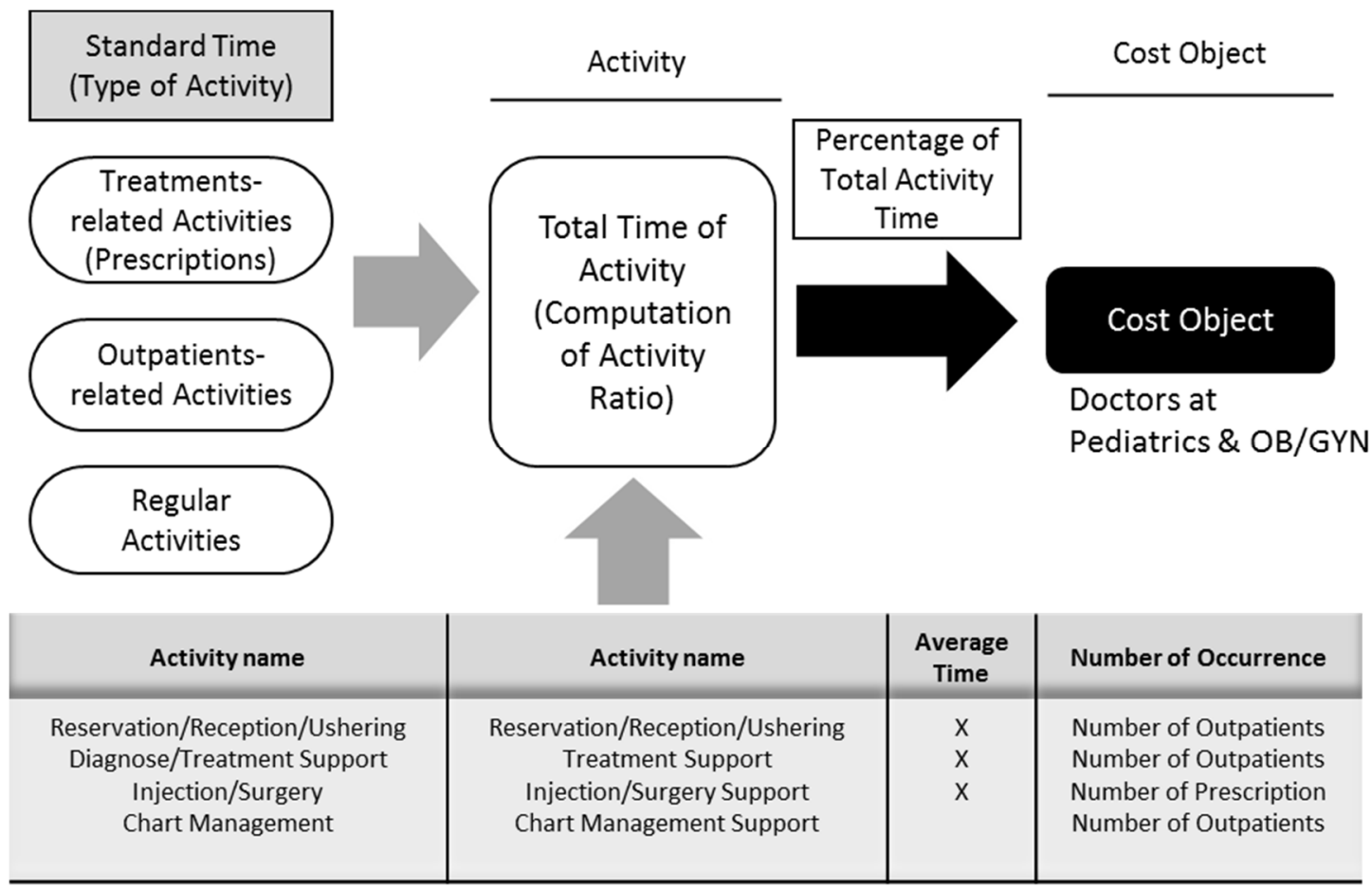

Table 3 shows outpatient nursing activities and activity ratios in the Pediatrics Department using TDABC. ${ }^{1}$

As much as $85 \%$ of the nursing activities was devoted to taking care of patients and $15 \%$ to supporting these activities. These percentages are very similar to those under traditional ABC. Among the patient care activities, three categories of activities (i.e., reservation, registration \& ushering; treatment \& diagnosis support; and inputting diagnosis \& prescription) all had activity ratios of approximately $25 \%$. The area of consultation \& education also had a significant ratio of $21 \%$. As much as $72 \%$ of the supporting activities originated from managing diagnosis schedules, and other categories had very small activity ratios. It should be noted that the standard time and activity ratio of 'registration of patients with no checkup for temperature \& weight' are -2 minutes and $-2.0 \%$, respectively. The negative numbers were caused by the fact that, of 2,903 patients, 412 patients did not need to check their temperature and weight; therefore, two minutes were subtracted. As shown in the table, the standard time for this activity was 3 minutes, and initially, three minutes were assigned as the standard time to all 2,903 patients.

As reported at the bottom of Table 3, we also examined the efficiency of nursing activities at Pediatrics Department as an organizational unit within the hospital. First, the theoretical capacity based on the Korean Labor Law was estimated from the following computation:

8 hours per day $\times 5.58$ nurses $\times 20.5$ days per month $=902$ FTE hours

Of 902 total hours, 677.2 hours $(75 \%)$ were spent for actual patient care and support activities, leaving the remaining 224.8 hours $(25 \%)$ as nonvalue-added activities. Hence, organizational efficiency at Pediatrics Department was 75 percent based on the theoretical resource capacity.

\footnotetext{
${ }^{1}$ It should be noted that a more detailed activity classification was used under TDABC. Each activity under traditional ABC as shown in Table 1 became a category and was sub-classified into individual activities as shown in Table 5.
} 
Table 3. Activity Ratios in the Pediatrics Department Using TDABC

\begin{tabular}{|c|c|c|c|c|c|c|c|}
\hline تֶ. & Category & Activity & $\begin{array}{l}\text { Number } \\
\text { of } \\
\text { activities }\end{array}$ & $\begin{array}{l}\text { Standard } \\
\text { time }\end{array}$ & Frequency & $\begin{array}{l}\text { Budgeted } \\
\text { hours }\end{array}$ & $\begin{array}{l}\text { Activity } \\
\text { ratio }\end{array}$ \\
\hline \multirow{13}{*}{ 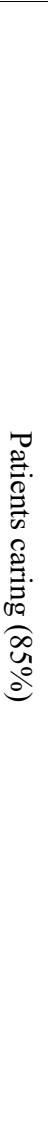 } & \multirow{2}{*}{$\begin{array}{l}\text { Reservation, } \\
\text { registration, \& } \\
\text { ushering }\end{array}$} & $\begin{array}{l}\text { Registration (receiving; } \\
\text { checking temperature \& } \\
\text { weight) }\end{array}$ & 2,903 & 3 minutes & $100 \%$ & 145.1 & $21.5 \%$ \\
\hline & & $\begin{array}{l}\text { Registration patients } \\
\text { with no checkup for } \\
\text { temperature \& weight }\end{array}$ & 412 & -2 minutes & $100 \%$ & -13.7 & $-2.0 \%$ \\
\hline & \multirow{2}{*}{$\begin{array}{l}\text { Consultation \& } \\
\text { education }\end{array}$} & $\begin{array}{l}\text { Training to use } \\
\text { Nebulizer machine }\end{array}$ & 17 & $\begin{array}{r}15 \\
\text { minutes }\end{array}$ & $30 \%$ & 1.3 & $0.2 \%$ \\
\hline & & $\begin{array}{l}\text { Managing immunization } \\
\text { schedule up to } 15 \\
\text { months }\end{array}$ & 1,469 & 5 minutes & $100 \%$ & 120.0 & $17.7 \%$ \\
\hline & \multirow{6}{*}{$\begin{array}{l}\text { Treatment \& } \\
\text { diagnosis support }\end{array}$} & $\begin{array}{l}\text { Measuring height \& } \\
\text { development }\end{array}$ & 179 & 5 minutes & $100 \%$ & 14.9 & $2.2 \%$ \\
\hline & & $\begin{array}{l}\text { Umbilical Granuloma } \\
\text { Tenancy Sul }\end{array}$ & 1 & 5 minutes & $100 \%$ & 0.1 & $0.0 \%$ \\
\hline & & $\begin{array}{l}\text { Conducting Glycerin } \\
\text { Enema }\end{array}$ & 11 & $\begin{array}{r}20 \\
\text { minutes } \\
\end{array}$ & $100 \%$ & 3.7 & $0.5 \%$ \\
\hline & & $\begin{array}{l}\text { Using Nebulizer TX } \\
\text { (breathing machine) }\end{array}$ & 17 & 5 minutes & $100 \%$ & 1.5 & $0.2 \%$ \\
\hline & & $\begin{array}{l}\text { Examining child } \\
\text { development }\end{array}$ & 2 & $\begin{array}{r}30 \\
\text { minutes }\end{array}$ & $100 \%$ & 0.8 & $0.1 \%$ \\
\hline & & $\begin{array}{l}\text { Auscultation \& } \\
\text { eyes/ears examination }\end{array}$ & 2,491 & 3 minutes & $100 \%$ & 124.5 & $18.4 \%$ \\
\hline & $\begin{array}{l}\text { Inputting diagnosis } \\
\& \text { prescription }\end{array}$ & $\begin{array}{l}\text { Order review for } \\
\text { tomorrow's patients }\end{array}$ & 2,903 & 3 minutes & $100 \%$ & 145.1 & $21.4 \%$ \\
\hline & $\begin{array}{l}\text { Managing patients' } \\
\text { charts }\end{array}$ & $\begin{array}{l}\text { Managing patients' } \\
\text { charts }\end{array}$ & 2,903 & & $100 \%$ & 21.5 & $3.2 \%$ \\
\hline & Sanitation & Sanitizing & 20.5 days & - & $100 \%$ & 10.8 & $1.6 \%$ \\
\hline \multirow{4}{*}{ 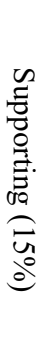 } & $\begin{array}{l}\text { Managing diagnosis } \\
\text { schedules }\end{array}$ & $\begin{array}{l}\text { Managing appointment } \\
\text { schedules }\end{array}$ & 162 & - & $100 \%$ & 73.2 & $10.8 \%$ \\
\hline & $\begin{array}{l}\text { Meetings \& } \\
\text { discussions }\end{array}$ & $\begin{array}{l}\text { Reading CT; MRI; } \\
\text { SONO; nuclear } \\
\text { treatment }\end{array}$ & 130 & 3 minutes & $100 \%$ & 6.5 & $1.0 \%$ \\
\hline & $\begin{array}{l}\text { Requisitioning \& } \\
\text { managing supplies }\end{array}$ & $\begin{array}{l}\text { Requisitioning \& } \\
\text { managing supplies }\end{array}$ & 20.5 days & - & $100 \%$ & 15.0 & $2.2 \%$ \\
\hline & $\begin{array}{l}\text { Education \& } \\
\text { training }\end{array}$ & Education \& training & 20.5 days & - & $100 \%$ & 6.8 & $1.0 \%$ \\
\hline \multicolumn{3}{|c|}{ Total } & & & & 677.1 & $100.0 \%$ \\
\hline \multicolumn{6}{|c|}{ Theoretical resource capacity } & 902.0 & $100 \%$ \\
\hline \multicolumn{6}{|c|}{ Non-value added activities } & 224.8 & $25 \%$ \\
\hline \multicolumn{6}{|c|}{ Organizational efficiency } & 677.2 & $75 \%$ \\
\hline
\end{tabular}

Using the activity ratios in the last column of Table 3, total outpatient nursing costs of $\$ 300,000$ were allocated to each activity category. The allocated costs in each category were then allocated to each Pediatrics doctor based on the consumption ratios of these activities by the doctor. The final allocated costs to each doctor are presented in Table 4. Because the relative time of each activity was used as the allocation base in TDABC, Doctor A, who spent the most time with outpatients, received the highest allocated costs of $\$ 63,526(21.1 \%)$, followed by Doctor E with $\$ 50,628$ (16.9\%). The lowest allocation was $\$ 18,468(6.2 \%)$ for Doctor H. These results are very similar to those under traditional $\mathrm{ABC}$, which are discussed above. A more detailed analysis of the costs will follow. 
Table 4. Allocated Costs to Each Doctor in the Pediatrics Department Using TDABC

\begin{tabular}{|c|c|c|c|c|c|c|c|c|c|}
\hline Nursing activities & $\begin{array}{c}\text { Doctor } \\
\text { A }\end{array}$ & $\begin{array}{c}\text { Doctor } \\
\text { B }\end{array}$ & $\begin{array}{l}\text { Doctor } \\
\text { C }\end{array}$ & $\begin{array}{l}\text { Doctor } \\
\text { D }\end{array}$ & $\begin{array}{l}\text { Doctor } \\
\text { E }\end{array}$ & $\begin{array}{c}\text { Doctor } \\
\text { F }\end{array}$ & $\begin{array}{c}\text { Doctor } \\
\text { G }\end{array}$ & $\begin{array}{c}\text { Doctor } \\
\text { H }\end{array}$ & Total \\
\hline $\begin{array}{l}\text { Registration } \\
\text { (receiving patients; } \\
\text { checking } \\
\text { temperature \& } \\
\text { weight) }\end{array}$ & $\$ 14,687$ & $\$ 8,747$ & $\$ 7,156$ & $\$ 6,029$ & $\$ 9,783$ & $\$ 9,576$ & $\$ 4,999$ & $\$ 3,317$ & $\$ 64,295$ \\
\hline $\begin{array}{l}\text { Registering patients } \\
\text { with no checkup for } \\
\text { temperature \& } \\
\text { weight }\end{array}$ & 0 & 0 & 0 & 0 & 0 & $-\$ 6,083$ & 0 & 0 & $-\$ 6,083$ \\
\hline $\begin{array}{l}\text { Training to use } \\
\text { Nebulizer machine }\end{array}$ & $\$ 144$ & $\$ 130$ & $\$ 14$ & $\$ 69$ & $\$ 163$ & $\$ 14$ & $\$ 44$ & $\$ 3$ & $\$ 581$ \\
\hline $\begin{array}{l}\text { Managing } \\
\text { immunization } \\
\text { schedule up to } 15 \\
\text { months }\end{array}$ & $\$ 8,306$ & $\$ 4,159$ & $\$ 7,476$ & $\$ 5,956$ & $\$ 11,232$ & $\$ 6,433$ & $\$ 5,018$ & $\$ 4,584$ & $\$ 53,164$ \\
\hline $\begin{array}{l}\text { Measuring height \& } \\
\text { development }\end{array}$ & $\$ 292$ & $\$ 5,473$ & $\$ 111$ & $\$ 418$ & $\$ 86$ & $\$ 129$ & $\$ 68$ & $\$ 37$ & $\$ 6,614$ \\
\hline $\begin{array}{l}\text { Umbilical } \\
\text { Granuloma Tenancy } \\
\text { Sul }\end{array}$ & 0 & 0 & 0 & 0 & $\$ 22$ & $\$ 3$ & $\$ 18$ & 0 & $\$ 43$ \\
\hline $\begin{array}{l}\text { Conducting Glycerin } \\
\text { Enema }\end{array}$ & $\$ 25$ & $\$ 1,292$ & $\$ 49$ & $\$ 135$ & $\$ 37$ & $\$ 86$ & 0 & 0 & $\$ 1,624$ \\
\hline $\begin{array}{l}\text { Using Nebulizer } \\
\text { TX(breathing } \\
\text { machine) }\end{array}$ & $\$ 160$ & $\$ 145$ & $\$ 15$ & $\$ 77$ & $\$ 182$ & $\$ 15$ & $\$ 49$ & $\$ 3$ & $\$ 646$ \\
\hline $\begin{array}{l}\text { Examining child } \\
\text { development }\end{array}$ & 0 & $\$ 111$ & 0 & $\$ 18$ & $\$ 37$ & $\$ 203$ & 0 & 0 & $\$ 369$ \\
\hline $\begin{array}{l}\text { Auscultation \& } \\
\text { eyes/ears } \\
\text { examination }\end{array}$ & $\$ 14,687$ & $\$ 8,747$ & $\$ 7,156$ & $\$ 6,029$ & $\$ 9,783$ & $\$ 452$ & $\$ 4,999$ & $\$ 3,317$ & $\$ 55,171$ \\
\hline $\begin{array}{l}\text { Order review for } \\
\text { tomorrow's patients }\end{array}$ & $\$ 14,687$ & $\$ 8,747$ & $\$ 7,156$ & $\$ 6,029$ & $\$ 9,783$ & $\$ 9,576$ & $\$ 4,999$ & $\$ 3,317$ & $\$ 64,295$ \\
\hline $\begin{array}{l}\text { Managing patients' } \\
\text { charts }\end{array}$ & $\$ 2,176$ & $\$ 1,296$ & $\$ 1,060$ & $\$ 893$ & $\$ 1,449$ & $\$ 1,419$ & $\$ 740$ & $\$ 491$ & $\$ 9,525$ \\
\hline Sanitizing & $\$ 1,026$ & $\$ 737$ & $\$ 570$ & $\$ 492$ & $\$ 813$ & $\$ 431$ & $\$ 403$ & $\$ 291$ & $\$ 4,762$ \\
\hline $\begin{array}{l}\text { Managing diagnosis } \\
\text { schedules }\end{array}$ & $\$ 5,217$ & $\$ 4,113$ & $\$ 3,779$ & $\$ 3,946$ & $\$ 4,565$ & $\$ 5,133$ & $\$ 3,461$ & $\$ 2,224$ & $\$ 32,440$ \\
\hline $\begin{array}{l}\text { Reading CT; MRI; } \\
\text { SONO; nuclear } \\
\text { treatment }\end{array}$ & $\$ 31$ & $\$ 670$ & $\$ 133$ & $\$ 262$ & $\$ 1,039$ & $\$ 236$ & $\$ 207$ & $\$ 293$ & $\$ 2,872$ \\
\hline $\begin{array}{l}\text { Requisitioning \& } \\
\text { managing supplies }\end{array}$ & $\$ 1,434$ & $\$ 1,030$ & $\$ 797$ & $\$ 687$ & $\$ 1,137$ & $\$ 602$ & $\$ 563$ & $\$ 406$ & $\$ 6,657$ \\
\hline Education \& training & $\$ 652$ & $\$ 468$ & $\$ 362$ & $\$ 312$ & $\$ 517$ & $\$ 273$ & $\$ 256$ & $\$ 185$ & $\$ 3,025$ \\
\hline Total & $\$ 63,526$ & $\$ 45,867$ & $\$ 35,835$ & $\$ 31,353$ & $\$ 50,628$ & $\$ 28,500$ & $\$ 25,823$ & $\$ 18,468$ & $\$ 300,000$ \\
\hline
\end{tabular}

\subsection{Comparative Analyses of Traditional $A B C$ and TDABC}

Table 5 shows the allocated costs to each doctor based on both traditional ABC (from Table 1) and TDABC (from Table 3). Except for Doctor F, the differences in the allocated costs under traditional ABC and TDABC are insignificant in percentage as shown in the last column of the table. ${ }^{1}$ The traditional $\mathrm{ABC}$ allocation for Doctor $\mathrm{F}$ was $\$ 44,991(15.0 \%)$, and the TDABC allocation was $\$ 28,500(9.5 \%)$ with a significant difference of $\$ 16,491$ $(5.5 \%)$.

\footnotetext{
${ }^{1} \mathrm{~T}$-value was 1.159418 , and p-value was 0.127716 . The test result was not significant at the 5-percent level.
} 
Table 5. Comparison of Allocated Costs for Each Doctor in the Pediatrics Department

\begin{tabular}{|c|c|c|c|c|c|c|}
\hline \multirow[b]{2}{*}{ Doctors } & \multicolumn{2}{|l|}{ Traditional } & \multicolumn{2}{|l|}{ TDABC } & \multirow[t]{2}{*}{ Differences } & \\
\hline & $\mathbf{A B C}$ & $\%$ & & $\%$ & & $\%$ \\
\hline Doctor A & 66,296 & $22.1 \%$ & 63,526 & $21.2 \%$ & $-2,770$ & $-0.9 p \%$ \\
\hline Doctor B & 40,510 & $13.5 \%$ & 45,867 & $15.3 \%$ & 5,357 & $1.8 \mathrm{p} \%$ \\
\hline Doctor C & 33,563 & $11.2 \%$ & 35,835 & $11.9 \%$ & 2,271 & $0.8 \mathrm{p} \%$ \\
\hline Doctor D & 29,051 & $9.7 \%$ & 31,353 & $10.5 \%$ & 2,302 & $0.8 \mathrm{p} \%$ \\
\hline Doctor E & 45,269 & $15.1 \%$ & 50,628 & $16.9 \%$ & 5,358 & $1.8 \mathrm{p} \%$ \\
\hline Doctor F & 44,991 & $15.0 \%$ & 28,500 & $9.5 \%$ & $-16,491$ & $-5.5 p \%$ \\
\hline Doctor $G$ & 24,281 & $8.1 \%$ & 25,823 & $8.6 \%$ & 1,542 & $0.5 p \%$ \\
\hline Doctor $\mathrm{H}$ & 16,038 & $5.3 \%$ & 18,468 & $6.2 \%$ & 2,430 & $0.8 \mathrm{p} \%$ \\
\hline Total & 300,000 & $100.0 \%$ & 300,000 & $100.0 \%$ & 0 & $0.0 \mathrm{p} \%$ \\
\hline
\end{tabular}

To understand why the allocation for Pediatrics Doctor F under traditional ABC was much greater than that under TDABC, a detailed activity analysis was conducted for Doctor F under both methods, and the comparison is presented in Table 6. It should be noted that the activities under TDABC have been adjusted to the activities under traditional $\mathrm{ABC}$ for the purpose of comparison. Under TDABC, the allocation from consultation/education and managing diagnosis schedules is much greater and that from treatment/diagnosis support, sanitation, and managing patients' charts is much less. In particular, the allocated amount from treatment \& diagnosis support is similar to other doctors under ABC, but significantly less under TDABC. The difference is caused by the use of a different allocation base. $\mathrm{ABC}$ allocated these costs to each doctor using the number of outpatients who visited the hospital, whereas TDABC used the number of outpatients who actually received the treatment and diagnosis support during the visit. Apparently, Doctor F had a similar number of outpatients as other doctors; however, the number of the patients who received treatment/diagnosis support was significantly less.

Table 6. Comparison of Allocated Costs for Doctor F in the Pediatrics Department

\begin{tabular}{|l|r|r|r|}
\hline \multicolumn{1}{|c|}{ Classification of activities } & Traditional ABC & TDABC & Differences \\
\hline Reservation, registration \& ushering & $\$ 5,535$ & $\$ 3,494$ & $\$ 2,042$ \\
\hline Consultation \& education & $\$ 2,801$ & $\$ 6,447$ & $-\$ 3,646$ \\
\hline Treatment/diagnosis support & $\$ 16,086$ & $\$ 889$ & $\$ 15,197$ \\
\hline Inputting diagnosis \& prescription & $\$ 8,803$ & $\$ 9,576$ & $-\$ 773$ \\
\hline Managing patients' charts & $\$ 4,468$ & $\$ 1,419$ & $\$ 3,050$ \\
\hline Diagnostic environment \& sanitation & $\$ 3,798$ & $\$ 431$ & $\$ 3,367$ \\
\hline Managing diagnosis schedules & $\$ 1,361$ & $\$ 5,133$ & $-\$ 3,773$ \\
\hline Meetings \& discussions & $\$ 334$ & $\$ 236$ & $\$ 98$ \\
\hline Requisitioning \& managing supplies & $\$ 735$ & $\$ 602$ & $\$ 133$ \\
\hline Recording \& statistics & $\$ 735$ & 0 & $\$ 735$ \\
\hline Education \& training & $\$ 334$ & $\$ 273$ & $\$ 61$ \\
\hline Total & $\$ 44,991$ & $\$ 28,500$ & $\$ 16,491$ \\
\hline
\end{tabular}

It should be noted that the activity ratios under traditional $\mathrm{ABC}$ were determined by the direct data input by the nurses as well as interviews of nurses, whereas under TDABC, the ratios were determined by the standard time, periodicity, and frequency of each activity. Hence, traditional $\mathrm{ABC}$ is more subjective, reflecting the opinions of the nurses, and open to manipulation. Activity ratios in TDABC are more objective, using scientific data to measure activities. To examine the difference in traditional $\mathrm{ABC}$ from Table 2 and TDABC from Table 5 in terms of the activities, the activity ratios are summarized in Table 7 . As clearly shown in the last column, there is little difference in the support activities; however, there is a significant difference in the nursing activities. The table also shows that, of a total 11 activity areas, the activity ratios are lower (with positive percentages in the last column) in seven areas under traditional $\mathrm{ABC}$ and higher (with negative percentages in the last column) in four areas. The consultation and education area has the largest difference of positive 11.6 percent, followed by the area of treatment/diagnosis support with negative 9.0 percent. In the process of data input under traditional $\mathrm{ABC}$, the time for certain activities (e.g., treatment/diagnosis support) was overstated, and the time for other activities (e.g., consultation and education) was understated. This was because of the subjective nature of the data collection process using questionnaires and surveys. 
Table 7. Comparison of Activity Ratios for Each Activity in the Pediatrics Department

\begin{tabular}{|c|c|c|c|c|c|c|}
\hline \multirow{2}{*}{ Domain } & \multirow{2}{*}{ Category } & \multirow{2}{*}{ Activity } & \multirow{2}{*}{$\begin{array}{c}\text { Traditional } \\
\text { ABC } \\
\text { Activity } \\
\text { ratios }\end{array}$} & \multicolumn{2}{|c|}{ TDABC } & \multirow{2}{*}{ Differences } \\
\hline & & & & $\begin{array}{l}\text { Activity } \\
\text { hours }\end{array}$ & $\begin{array}{l}\text { Activity } \\
\text { ratios }\end{array}$ & \\
\hline \multirow{6}{*}{$\begin{array}{l}\text { Patient } \\
\text { caring } \\
\text { activities }\end{array}$} & \multirow{2}{*}{$\begin{array}{l}\text { Reservation \& } \\
\text { ushering }\end{array}$} & $\begin{array}{l}\text { Reservation, } \\
\text { registration \& ushering }\end{array}$ & $12.4 \%$ & 131.4 & $19.4 \%$ & $7.0 \%$ \\
\hline & & $\begin{array}{l}\text { Consultation \& } \\
\text { education }\end{array}$ & $6.3 \%$ & 121.3 & $17.9 \%$ & $11.6 \%$ \\
\hline & \multirow{4}{*}{$\begin{array}{l}\text { Medical } \\
\text { treatment \& } \\
\text { support }\end{array}$} & $\begin{array}{c}\text { Treatment/diagnosis } \\
\text { support }\end{array}$ & $30.4 \%$ & 145.5 & $21.5 \%$ & $-9.0 \%$ \\
\hline & & $\begin{array}{c}\text { Inputting diagnosis \& } \\
\text { prescription }\end{array}$ & $19.7 \%$ & 145.1 & $21.4 \%$ & $1.7 \%$ \\
\hline & & $\begin{array}{l}\text { Managing patients' } \\
\text { charts }\end{array}$ & $10.0 \%$ & 21.5 & $3.2 \%$ & $-6.8 \%$ \\
\hline & & $\begin{array}{c}\text { Diagnostic } \\
\text { environment \& } \\
\text { sanitation }\end{array}$ & $8.1 \%$ & 10.8 & $1.6 \%$ & $-6.5 \%$ \\
\hline \multirow{5}{*}{$\begin{array}{l}\text { Support } \\
\text { activities }\end{array}$} & \multirow{2}{*}{$\begin{array}{l}\text { Cooperation \& } \\
\text { adjustments }\end{array}$} & $\begin{array}{l}\text { Managing diagnosis } \\
\text { schedules }\end{array}$ & $8.4 \%$ & 73.2 & $10.8 \%$ & $2.5 \%$ \\
\hline & & $\begin{array}{l}\text { Meetings \& } \\
\text { discussions }\end{array}$ & $0.7 \%$ & 6.5 & $1.0 \%$ & $0.2 \%$ \\
\hline & \multirow{4}{*}{ Administration } & $\begin{array}{l}\text { Requisitioning \& } \\
\text { managing supplies }\end{array}$ & $1.6 \%$ & 15.0 & $2.2 \%$ & $0.6 \%$ \\
\hline & & Recording \& statistics & $1.6 \%$ & 0.0 & $0.0 \%$ & $-1.6 \%$ \\
\hline & & Education \& training & $0.7 \%$ & 6.8 & $1.0 \%$ & $0.3 \%$ \\
\hline & & Total & $100.0 \%$ & 0.0 & $100.0 \%$ & $0.0 \%$ \\
\hline
\end{tabular}

\section{Conclusion}

The main purpose of this study was to examine the effectiveness and accuracy of TDABC, which had been suggested by Kaplan and Anderson (2004), using the Pediatrics Department at a University Hospital in South Korea. Because most previous studies had focused on the analyses of activity costs at the independent department level of hospitals, we conducted detailed cost analyses for each doctor to identify the unused capacity (i.e., nonvalue-added activities) for each doctor to ensure that the results of this study could be used to provide top management with a strategic direction for budgeting and employee motivation. In interpreting the results, however, it should be noted that medical institutions also have social responsibilities to improve the health and well-being of the people; therefore, solely pursuing profit under TDABC could undermine the long-term reputation and sustainability of the hospital.

It has been found that the costs of nursing activities allocated to most doctors were not very different between the traditional $\mathrm{ABC}$ and TDABC. Although TDABC is less complicated and less costly to implement and maintain than traditional $\mathrm{ABC}$, the results of this study clearly demonstrate that the allocated costs using TDABC would be as accurate as those using traditional $\mathrm{ABC}$. In addition, TDABC uses less cost drivers in the allocation process; therefore, it can be argued that TDABC is more effective and efficient than traditional ABC for hospitals. In fact, Kaplan and Anderson (2007) emphasize the accuracy of the cost based on a simple method rather than the precision of the cost based on a complicated method requiring a huge amount of data. Another advantage of TDABC is that it helps identify value-added and nonvalue-added activities and provide a strategic direction in reducing nonvalueadded activities. Such information regarding organizational efficiency that can provide new insight on future performance management and internal control is generally not available in traditional ABC. From the strategic decision making perspective, TDABC can provide other valuable information, which would not be available under traditional $\mathrm{ABC}$, such as more realistic cost information. Using the information, a more realistic profit forecast is possible, and the allocation of scarce resources can be more effectively performed. Budget revisions are made possible based on the workflow process and time equation for each doctor and/or department. The future demand of scarce resources can be estimated based on the revised budget. Based on TDABC information, hospital staff will be encouraged to use personnel and physical resources more efficiently, and purchasing and hiring decisions will be more effective by eliminating the asymmetry of information on unused resources. The visibility of unused 
resources will be improved on all levels of management in the hospital.

It should be noted that the scope of this study is limited to the allocation of outpatient nursing costs to doctors at a non-profit university hospital. To generalize the conclusion of the study, more research should be done, including other hospital costs, such as medical equipment, non-medical supporting staff, etc. for non-profit and for-profit hospitals as well. Considering the popularity of $\mathrm{ABC}$ in the manufacturing sector around the world, it will also be interesting to do more comparative case studies between traditional ABC and TDABC for the manufacturing industry.

\section{References}

Amadeo, K. (2019). The Rising Costs of Healthcare by Year and Its Causes, https://www.thebalance.com/causesof-rising-healthcare-costs-4064878 (updated May 05, 2019).

Bank, D. E., and T. Mcllrath (2009). Utilizing Time-Driven Activity-Based Costing in the Emergency Department, Annals of Emergency Medicine, Vol. 54, No. 3, p. S5.

Cooper, R. and R.S. Kaplan (1998). The promise and peril of integrated cost Systems, Harvard Business Review, 76(4), pp. 109-119.

Cao, P., S. Toyabe, S. Kurashima, M. Okada, and K. Akazawa (2006). A modified method of activity-based costing for objectively reducing cost drivers in hospitals, Methods Inf Med, Vol. 45, No. 4, pp. 462-469.

Carr, L.P. (1993). Unbundling the cost of hospitalization, Management Accounting. 75.5 (Nov 1993): pp. 43-48.

Cook, C., G. Cole, P. Asaria, R. R. Jabbour, and D. P. Francis (2014). The annual global economic burden of heart failure, International Journal of Cardiology (Volume 171; Issue 3), PP. 368-376.

Demeere, N., K. Stouthuysen, and F. Roodhooft (2009). Time-driven activity-based costing in an outpatient clinic environment: development, relevance and managerial impact. Health Policy (Vol. 92), 296-304.

Everaert, P., W. Bruggeman, and G. Creus (2008). Sanac Inc.: From ABC to time-driven ABC (TDABC) - An instructional case. Journal of Accounting Education, 26, 118-154.

Kaplan, R. S., \& Anderson, S. R. (2004). Time-driven activity-based costing. Harvard Business Review, 82, 131138.

Kaplan, R. S., \& Anderson, S. R. (2007). The innovation of time-driven activity-based costing. Journal of Cost Management, 21(2), 5-15.

Kaplan, R. S. and Norton, (2008). Mastering the management system. Harvard Business Review, 88, 62-77.

Kaplan, R. S., Porter, M. E. (2011). How to solve the cost crisis in health care. Harvard Business Review, 89, 4664.

Lievens Y, Van Den Bogaert W, Kesteloot K (2003). Activity-based costing: a practical model for cost calculation in radiotherapy. International Journal of Radiation Oncology Biology Physics, 57(2), 522-35.

Lin, B. Y., T. Chao, Y. Yao, S. Tu, C. Wu, J. Chern, S. Chao, and K. Shaw. (2007). How Can Activity-Based Costing Methodology Be Performed as a Powerful Tool to Calculate Costs and Secure Appropriate Patient

Care? J Med Syst 31:85-90

Pearl, R. (2017) Why Major Hospitals Are Losing Money By The Millions, Forbes (November 7, 2017) https://www.forbes.com/sites/robertpearl/2017/11/07/hospitals-losing-millions/\#24a0cc2a7b50

Ramsey RH 4th (1994). Activity-based costing for hospitals. Hosp Health Serv Adm, 39(3), 385-396.

Seuring, T., O. Archangelidi, and M. Suhrcke (2015). The Economic Costs of Type 2 Diabetes: A Global Systematic Review, PharmacoEconomics, 22 (8), pp. 811-831.

Storfjell, J. L., O. Omoike, S. Ohlson (2008). The balancing act: patient care time versus cost. J Nurs Adm, 38(5), 244-249.

Storfjell, J. L., S. Ohlson, O. Omoike (2009). Non-value-added time: The million dollar nursing opportunity. $J$ Nurs Adm, 39(1), 38-45.

Wikipedia (2017). Health care in the United States. March 2017 https://en.wikipedia.org/wiki/Health_care_in_the_United_States

Yereli, A. N. (2009). Activity-based costing and its application in a Turkish university hospital. AORN Journal (Vol. 89; No. 3), 573-591. 